\title{
Who pays the most cigarette tax in Turkey
}

\author{
Zeynep Önder, ${ }^{1}$ Ayda A Yürekli ${ }^{2}$
}

- Additional material is published online only. To view please visit the journal online (http://dx.doi.org/10.1136/ tobaccocontrol-2014-051639).

${ }^{1}$ Faculty of Business Administration, Bilkent University, Ankara, Turkey ${ }^{2}$ Tobacco Control Economics Unit, Prevention of Noncommunicable Diseases Department, World Health Organization

\section{Correspondence to} Dr Zeynep Önder, Faculty of Business Administration, Bilkent University, Bilkent, Ankara 06800, Turkey; zonder@bilkent.edu.tr

Received 27 February 2014 Accepted 27 August 2014 Published Online First 16 September 2014

\section{CrossMark}

To cite: Önder $Z$ Yürekli AA. Tob Control 2016;25:39-45.
ABSTRACT

Background Although higher taxation of tobacco products is considered the most cost-effective tobacco control policy, its negative impact on low-income groups is one of the arguments used against it.

Objective To investigate the impact of current excise taxes and the increases of excise taxes on tobacco and household expenditures by expenditure tertiles, and examine who pays excise taxes in general.

Method Impacts of excise taxes on cigarettes are examined with a budgetary approach. We first estimate the price elasticity of cigarettes by expenditure tertiles using data from the 2003 Turkish Household Expenditure Survey, the most recent data set covering detailed tobacco product information relevant to our analysis. We then conduct a number of simulation analyses by increasing the excise taxes per pack of cigarettes and examine the impacts of these increases on household expenditures. Finally, as excise tax increases, we predict the total excise tax paid by households in different expenditure tertiles and compare the concentration curve of excise tax spending with the Lorenz curve showing the cumulative share of total household expenditures by expenditure tertiles. We estimate the progressivity coefficient that measures the area between the Lorenz and concentration curves.

Results The low-income group is found to be the most sensitive to tax and price increases. It spends a relatively higher share of the household expenditure on cigarettes compared with higher income groups. However, the results suggest a different outcome as excise tax increases; the share of household expenditures spent on cigarettes declines for all household tertiles but a significant reduction occurs on the lowest expenditure tertile, suggesting that increases in excise taxes are progressive. Furthermore, the highest expenditure tertile pays the highest excise tax among expenditure tertiles, and their share in total excise revenue increases as the excise tax per pack of cigarettes increases.

Conclusions The poor smoking households benefit the most from increases in excise taxes; from a budgetary perspective, as they reduce their smoking consumption significantly, the share of their excise payment in total household expenditures declines. From a health perspective, they are likely to have more health benefits as their consumption reduces. Government revenues are also predicted to increase with increased excise taxes, and the government can allocate a part of these revenue increases on implementing and enforcing other tobacco control measures including cessation support and smokefree environments.

\section{INTRODUCTION}

Increasing taxes on tobacco products is found to be one of the most cost-effective ways of preventing tobacco-attributable deaths and diseases. ${ }^{12}$ This policy tool is especially useful in developing countries where $70 \%$ of tobacco-related preventable deaths are expected to occur by $2030 .{ }^{1}$ Despite the expected benefits, governments have many concerns about increases in excise taxes, particularly the impact of higher taxes on poor smokers.

A wealth of studies examine whether taxes create burdens on low-income households. Some economists claim that the impact of cigarette excise taxes is higher on the poor since the poor disproportionately smoke tobacco more than the rich, and that they spend a larger share of their income on tobacco. ${ }^{3-13}$ Evidence from low-income and middle-income countries report that the share of cigarette expenditure in household income or expenditure varies between $4.25 \%$ and $7.2 \%$ for low-income households and between $1.65 \%$ and $3 \%$ for the higher income households. ${ }^{14-17}$

Taxes are classified as regressive when the poor pay a higher share of their income in tax than the rich. As taxes increase, those who continue to smoke will be hurt by higher taxes, and those who quit will be worse off because they gave up something that gave them higher utility. ${ }^{18-20}$ Chaloupka and Warner ${ }^{19}$ argue that tax increases may not be regressive since tax-induced behavioural change towards quitting will benefit poor smokers' health as well as savings that would otherwise be spent on tobacco consumption because the poor are more sensitive to higher prices than the rich in lowincome and middle-income countries where price elasticity ranges from -1.9 to -0.15 among the poor and -1.48 to +0.51 among the rich. ${ }^{2 \mathrm{i}}$

Evidence from the existing literature is mixed in terms of who carries the increase in tax burden when excise taxes on tobacco increase. For example, Townsend ${ }^{4} 5$ finds that those in the lowest social class are more sensitive to price changes; they are more likely to alter their smoking behaviour to reduce the burden of tax increases. Borren and Sutton ${ }^{8}$ find that men in the lowest social class pay over eight times more in increased tax than men in the highest social class in the UK. Viscusi ${ }^{12}$ argues that cigarette taxes in the USA fell predominantly on the very poor. Gospodirov and Irvine $^{21}$ find that price elasticity for different socioeconomic groups is almost flat, and therefore the concerns about burden of tax increases are valid for Canada. ${ }^{\text {ii }}$ On the other hand, Younger et $a l^{22}$ found that in Madagascar excise taxes on tobacco are progressive but argue that households underreport their tobacco and alcohol consumption in

iPlease see chapter 5[2] for a detailed summary of existing price elasticity literature.

${ }^{i i}$ Other summary discussions of the impact of cigarette excise taxes are in [2] and [18]. 
their survey. In another study, Rajemison et $a l^{23}$ combine cigarettes and Parkaway, which is not taxed and mostly consumed by the poor, and report that tobacco excises are neutral in Madagascar.

In this paper, we have two aims. The first aim is to shed light on the argument on whether increases in excise taxes put a burden on the poor smokers by using a budgetary approach, and how tax-induced price increases affect their smoking behaviour. The second aim, from the policy perspective, is to show the impact of excise increases on tax revenues and to determine who pays the taxes so that the governments can allocate extra revenues for smoking cessation for those who cannot quit smoking. To achieve these aims, we will examine the impact of increases in excise taxes on cigarettes by expenditure tertiles in Turkey. Turkey is an interesting country with a high smoking prevalence and intensity of smoking where $27.1 \%$ of adults smoke cigarettes as of $2012 .{ }^{24}$ Furthermore, the share of excise and total taxes on retail price increased from $55.3 \%$ and $70.5 \%$ in 2003 to $65.3 \%$ and $81 \%$ in 2013 , respectively.

\section{DATA AND METHODOLOGY}

\section{Data}

This study uses the 2003 Turkish National Household Expenditure Survey (THES), conducted by the Turkish Statistical Institute (TSI). It is a nationally representative randomly selected household survey that covers urban (eg, population over 20000 ) and rural areas of 12 regions in Turkey. The total number of households surveyed is 25764 . This is the only available of household data that records all household expenditures including tobacco products and cigarettes by brand.

The data represent household income and consumption patterns as well as expenditures on goods and services. Members of households who agree to participate in the survey are asked to record their daily consumption and expenditures during a period of 1 month. Expenditures include food and nonalcoholic drinks, alcohol and cigarettes, outwear and shoes, household utilities, furniture, health, transportation, communication, entertainment, education, recreation and other goods and services that the household buys during the month of the survey. The consumption and expenditure patterns are recorded by household level, as the demographic and socioeconomic characteristics of the household head as well as each household member are recorded. These include age; sex; employment status; if unemployed, the reasons; types of work engaged in; income earned; education level; and type of health insurance, if they have any.

\section{Methodology}

The methodology of this study consists of two parts. First, we categorise households into three expenditure tertiles based on their per capita-household expenditure levels and estimate the cigarette demand using a two-part demand model. Second, we examine the incidence of existing cigarette taxes and increases in cigarette excises according to the budgetary approach by using the parameters estimated by the demand model. Here, we estimate the impacts of current cigarette taxes and increases in cigarette taxes by each expenditure tertile. Then we draw concentration curves of tobacco tax expenditures, pretax and post-tax increases and a Lorenz curve ${ }^{\text {iii }}$ for household

iii In economics, the Lorenz curve is used to identify the inequality of income distribution. It shows the percentage of expenditures paid by the expenditure by adopting the methodology developed by Yitzhaki and Slemrod. ${ }^{25}$ We estimate the progressivity coefficient $^{\text {iv }}$ similar to that adopted by Younger, ${ }^{26}$ the area between the concentration curve for total household expenditures (Lorenz curve) and the concentration curve for taxes paid.

Smoking behaviour of households: demand for tobacco products A two-part model developed by $\mathrm{Cragg}^{27}$ is used to estimate the price elasticity of cigarette demand. In the first stage, the household's propensity to smoke is estimated by using a logit model. A household that has positive tobacco expenditure is identified as a 'smoker household.' The dependent variable, SMOKER, takes the value 1 if the household has positive tobacco expenditure (smoker households) and zero otherwise. The following logit model is estimated:

$$
\text { Probability }(\text { SMOKER }=1)=\pi_{i}=\frac{e^{\left(\beta_{0}+\beta X_{i}\right)}}{1+\mathrm{e}^{\left(\beta_{0}+\beta X_{i}\right)}}
$$

where $\mathrm{X}_{\mathrm{i}}$ is the vector of explanatory variables representing the price measured with the total expenditure per pack of 20 cigarettes, total household expenditure as a proxy for household income and the other socioeconomic and demographic characteristics of household i. These variables are listed in table 1 . $\beta$ represents the vector of coefficients of explanatory variables in the model.

In the second stage, a conditional demand model is applied to estimate the intensity of smoking by smoker households only. The dependent variable is the natural logarithm of the number of packs of 20 cigarettes purchased by the household i during the month of the interview $\left(\ln C_{i}\right)$. The following model is estimated using an ordinary least squares regression technique.

$$
\mathrm{LnC}_{\mathrm{i}}=\theta_{0}+\theta_{1} \ln \left(\mathrm{Xp}_{\mathrm{i}}\right)+\theta^{\prime} \mathrm{X}_{\mathrm{i}}+\varepsilon_{\mathrm{i}}
$$

$\mathrm{C}_{\mathrm{i}}$ includes all tobacco products including cigarettes, cigarillos and loose tobacco consumed in a household. The quantities of non-cigarette products consumed by the households are converted to cigarettes by assuming that $1 \mathrm{~g}$ of loose tobacco is equivalent to one cigarette and one cigarillo is the same as one cigarette. $^{\mathrm{v}} \theta_{1}$ is the price (expenditure) elasticity of tobacco demand and $\theta^{\prime}$ is the vector of coefficients corresponding to the vector of explanatory variables $\mathrm{X}_{\mathrm{i}}$, as explained in table 1 . The same explanatory variables are used in both models.

The price of a cigarette $\left(\mathrm{Xp}_{\mathrm{i}}\right)$ is estimated by dividing the total tobacco expenditure of the household $\mathrm{i}$ by their total

bottom $\mathrm{x} \%$ of households. The $\mathrm{x}$-axis shows the percentage of households whereas the $y$-axis shows the percentage of expenditures spent by that group. It plots the cumulative expenditures against the cumulative distribution of households. The more convex the Lorenz curve, the greater the inequality of household expenditures. The $45^{\circ}$ line indicates the equality of distribution over all household percentiles. ${ }^{i v}$ If the share of taxes paid by household tertiles equals to the share of these tertiles in household expenditures, then progressivity coefficient will be zero. It is negative (positive) if the concentration curve of tax payments is less (more) convex than the concentration curve of household expenditures (Lorenz curve). A negative coefficient indicates that the share of each tertile in tax expenditures is higher than the share of tertiles in household expenditures. Negative (Positive) values indicate a regressive (progressive) tax.

${ }^{\mathrm{v} I n}$ the survey, there were 14866 smoker households. Only one household reported that they consumed cigars; three households reported that they consumed pipe tobacco; 84 households reported that they purchased loose tobacco during the month of the survey. 
Table 1 Definition, mean and SD of the explanatory variables

\begin{tabular}{|c|c|c|c|}
\hline Variables by Household i & Definition & All households & Smoker households \\
\hline $\ln (X p)_{i}$ & The natural logarithm of the tobacco expenditure equivalent to per pack of 20 cigarettes & & $14.25(0.19)$ \\
\hline $\ln (\mathrm{HXpPc})_{\mathrm{i}}$ & The natural logarithm of total household expenditure per adult equivalent* & $19.34(0.68)$ & $19.38(0.66)$ \\
\hline Age $_{\mathrm{i}}$ & The share of household members 15 years old or younger & $0.25(0.23)$ & $0.27(0.22)$ \\
\hline Age $_{i}$ & The share of household members 55 years old or older & $0.17(0.31)$ & $0.11(0.23)$ \\
\hline $\mathrm{Edu}_{\mathrm{i}}$ & The share of adults with education equivalent to high school and above & $0.26(0.35)$ & $0.27(0.35)$ \\
\hline Married $_{2}$ & Equals 1 if the household head is married, zero otherwise & $0.89(0.31)$ & $0.91(0.28)$ \\
\hline $\operatorname{AdMALE}_{\mathrm{i}}$ & The percentage share of an adult male & $0.35(0.18)$ & $0.36(0.18)$ \\
\hline Unemp $_{\mathrm{i}}$ & The percentage of adult household members currently looking for a job & $0.04(0.12)$ & $0.04(0.13)$ \\
\hline Manlns $_{\mathrm{i}} \dagger$ & The percentage of household members who have mandatory health insurance coverage & $0.64(0.45)$ & $0.62(0.45)$ \\
\hline Vollns $_{\mathrm{i}}$ & The percentage of household members who have voluntary health insurance coverage & $0.01(0.09)$ & $0.01(0.08)$ \\
\hline WhiteCol $_{\mathrm{i}}$ & The percentage of adults who have a professional occupation & $0.64(0.34)$ & $0.61(0.33)$ \\
\hline Post_July ${ }_{i}$ & Equals 1 if the household was interviewed before July, zero otherwise & $0.42(0.49)$ & $0.41(0.49)$ \\
\hline $\mathrm{N}$ & Number of households & 25764 & 14868 \\
\hline
\end{tabular}

tobacco product consumption measured in units of 20 cigarettes a pack among smoking households. ${ }^{\mathrm{vi}}$ We first estimate the average price per pack by region and within region by rural and urban areas and by the month of survey. Then we calculate the weighted average price for each subgroup and those values are assigned to each household in these subgroups regardless of their smoking status in order to eliminate the endogeneity problem. We assume that since non-smoking households do not report any expenditure on tobacco, they still face a price regardless of their smoking status and that may affect their nonsmoking behaviour.

The surveys were conducted during 2003 and the average monthly inflation rate was $1.43 \%$. Each household was surveyed only once during the year. Therefore, in order to compare all households, all monetary values (prices, taxes and expenditures) are deflated to June 2003 levels using the consumer price index. All estimates are weighted, so the results can be generalised for the whole nation. We classify households based on total household expenditures per adult equivalent and estimate equations (1) and (2) for each of the expenditure tertiles.

\section{Tax incidence analysis}

The budgetary approach takes the traditional view of incidence analysis; it compares the share of cigarette taxes on the household expenditures, and calculates the tax burden by income or expenditure groups. Using this approach, we estimate the current as well as increases in excise tax incidence by expenditure tertiles.

The excise tax rate $(t)$ applied to all tobacco products in 2003 is the same. It was $49.5 \%$ of the retail price between January and July; at the beginning of August, the rate increased to $55.3 \%$ of the retail price, inclusive of excise tax, ${ }^{\text {vii }}$ value added tax (VAT) and retailers' margin. The statutory VAT rate is $18 \%$, which is equivalent to $15.25 \%$ of retail price. Hence, the price

\footnotetext{
${ }^{\text {vi Deaton }}{ }^{28}$ identifies that the ratio of total cigarette expenditure to total cigarettes as expenditure rather than price per pack of cigarettes and its elasticity as expenditure elasticity rather than price elasticity. For the sake of convenience, we refer them as price and price elasticity.

${ }^{\text {vii } W e ~ m u l t i p l i e d ~ t h e ~ e x p e n d i t u r e ~ w i t h ~ t h e ~ a p p r o p r i a t e ~ e x c i s e ~ t a x e s ~ f o r ~}$ those households who reported their tobacco expenditures during the months before and after July 2003.
}

or household tobacco expenditure per pack $\left(\mathrm{Xp}_{\mathrm{i}}\right)$ has the following components:

$$
\begin{aligned}
\mathrm{Xp}_{\mathrm{i}} & =\text { Producer Price } \\
& + \text { Excise } \operatorname{tax}+\mathrm{VAT}=\text { Producer Price }+\left(\mathrm{X} \mathrm{p}_{\mathrm{i}} \times \mathrm{t}\right) \\
& +\left(\mathrm{Xp}_{\mathrm{i}} \times 0.1525\right)
\end{aligned}
$$

For the sake of simplicity, we assume that producers adjust retailers' margin from their own price. We estimate the total excise tax expenditure $\left(\mathrm{EX}_{\mathrm{Pk}}\right)$ spent by each expenditure tertile $\mathrm{k}$ as follows:

$$
\mathrm{EX}_{\mathrm{k}}=\mathrm{N}_{\mathrm{k}} \times \overline{\pi_{\mathrm{k}}} \times \overline{\mathrm{C}_{\mathrm{k}}} \times \overline{\mathrm{T}_{\mathrm{k}}}
$$

where $\mathrm{N}_{\mathrm{k}}$ is the number of households, $\overline{\pi_{\mathrm{k}}}$ is the mean predicted smoking prevalence rate of households, $\overline{C_{k}}$ is the predicted mean consumption of smoker households and $\overline{T_{k}}$ is the average excise tax paid per pack by households in expenditure tertile $k$. Then the excise tax incidence by tertile $\mathrm{k}$ is estimated as:

$$
\mathrm{I}_{\mathrm{T}_{\mathrm{k}}}=\frac{\mathrm{EX} \mathrm{p}_{\mathrm{k}}}{\mathrm{HX} \mathrm{p_{k }}}
$$

where $\mathrm{HX} \mathrm{p}_{\mathrm{k}}$ is total smoker households' expenditure in tertile $\mathrm{k}$.

In order to investigate the impact of the increase in excise tax on tax incidence, we hypothetically increase the excise value per pack paid by each household by $10 \%, 25 \%, 50 \%$ and $75 \%$. We assume that producers fully transfer the tax increases to consumer prices. As excise tax increases, the new price per pack paid by each household, $\overline{\mathrm{Xp}_{\mathrm{i}}}$, is predicted as follows:

$$
\overline{\overline{\mathrm{Xp}}}=\text { Producer Price }+\overline{\overline{\mathrm{T}_{\mathrm{i}}}}+\overline{\overline{\mathrm{V}_{\mathrm{i}}}}
$$

where $\overline{\overline{T_{i}}}=$ Old excise tax $/$ pack $\times(1+\tau)$ is the new excise tax expenditure per pack, and $\tau$ is the rate of excise per pack increases as mentioned above. $\overline{\overline{V_{i}}}=\left[15.25 \% \times \overline{\overline{\mathrm{Xp}_{\mathrm{i}}}}\right]$ is the new VAT tax paid per pack. The tax incidence of higher excise tax on household tertiles are estimated using the percentage change in the prices as a result of a hypothetical increase in excise taxes, total price elasticity reported in table 4 and the percentage change in total cigarette consumption for each tertile. 
Table 2 Smoking prevalence rates and intensity in 2003

\begin{tabular}{|c|c|c|c|c|}
\hline & \multirow[b]{2}{*}{ All households } & \multicolumn{3}{|c|}{ Expenditure tertiles } \\
\hline & & The poor & Middle & The rich \\
\hline Smoking prevalence rate by households (\%) & 57.6 & 54.1 & 59.1 & 59.5 \\
\hline Average tobacco expenditures (price)/pack equivalent (in TL)* & 1.58 & 1.47 & 1.59 & 1.67 \\
\hline Average number of packs smoked by smoking households per month & 32.5 & 31.5 & 32.7 & 33.1 \\
\hline Average number of packs smoked per adult in smoking households per month & 13.2 & 11.0 & 13.5 & 15.5 \\
\hline Number of households (unweighted) & 25764 & 9023 & 8817 & 7924 \\
\hline Number of households (weighted) & 16735975 & 5523059 & 5689296 & 5523619 \\
\hline
\end{tabular}

Source: Authors' calculations using the 2003 Turkish National Household Expenditure Survey data.

${ }^{*}$ In June 2003, US\$1 was $1.41 \mathrm{TL}$.

We estimate a progressivity coefficient, the area between the share of excise tax payments (concentration curve) and the share of total household expenditures, in order to understand whether the tax increases are progressive overall. The coefficient is bounded by $(1+G)$ and $(1-G)$, where $G$ is the Gini coefficient for expenditures. ${ }^{\text {viii }}$

\section{RESULTS}

\section{Descriptive analysis}

The intensity and prevalence rate of smoking by all households and expenditure tertiles are reported in table 2 . Both the prevalence of smoking households and the intensity of smoking are higher in the high expenditure tertile. Intensity of smoking increases when we estimate the consumption level by per adult equivalent, based on the average number of adults per household over 15 years of age. Clearly, the higher the expenditure of households (eg, rich households), the higher the intensity of smoking. High, middle and low expenditure tertiles spend on average $\$ 1.18, \$ 1.13$ and $\$ 1.04 /$ pack of cigarettes, respectively.

The total monthly quantity of tobacco use (equivalent to a pack of 20 cigarettes) is estimated ${ }^{\text {ix }}$ to be around 313 million packs where the low, middle and high tertiles smoke 30\%, 35\% and $34 \%$, respectively, of the total reported quantity of cigarette consumption (table 3 ). Turkish households spend approximately US\$338 million per month in terms of June 2003 prices on cigarettes, which is equivalent to $6.3 \%$ of the total monthly household expenditure of smoker households.

As expected, the burden of tobacco expenditure decreases as household expenditure increases (table 3). In 2003, it is estimated that the poor spend a higher share of total household expenditure-about $10 \%$ on tobacco, whereas the rich spend $4.5 \%$. The poor also pay a higher percentage of their total household expenditure on excise tax: $5.2 \%$ compared with the rich households' 2.4\%. However, the total excise paid in 2003 is estimated to be around US\$176 million per month, and the rich pay more than $42.5 \%$ of the total excise tax revenues while the poor pay only $23 \%$.

\footnotetext{
${ }^{\text {viii Let }}\left(\mathrm{X}_{\mathrm{k}}, \mathrm{Y}_{\mathrm{k}}\right)$ be the known points on the Lorenz curve, where $\mathrm{X}_{\mathrm{k}}$ is indexed in increasing order $\left(\mathrm{X}_{\mathrm{k}-1}<\mathrm{X}_{\mathrm{k}}\right)$ and is the cumulated proportions on the horizontal line (in our case, tertiles) for $k=0,1, \ldots, 5$, where $\mathrm{k}$ is tertile with $\mathrm{X}_{0}=0$ and $\mathrm{X}_{5}=1$, and $\mathrm{Y}_{\mathrm{k}}$ is the cumulated proportion of expenditure or the tax-paid variable for $\mathrm{k}=0,1,2,3$, with $\mathrm{Y}_{0}=0$ and $\mathrm{Y}_{3}=1$. Then, the Gini coefficient is calculated as follows: $\mathrm{G}=1-\sum_{k=1}^{3}\left(\mathrm{X}_{k}-\mathrm{X}_{k-1}\right)\left(\mathrm{Y}_{k}+\mathrm{Y}_{k-1}\right)$.

ix The total tobacco use is estimated using the THES data and the weights of each household surveyed. It represents the total consumption in the survey year in Turkey.
}

\section{Elasticity estimates}

Table 4 reports the price and income elasticity of demand for cigarettes by expenditure tertiles calculated using a bootstrapping technique. The results of the two-part model are presented in the online appendix (table A). The price and income sensitivity of smoking participation is found to decrease monotonically with expenditure. Both the participation and conditional demand elasticities are found to be highest (in absolute terms) for the poor households. It is consistent with the elasticity estimates in other developing countries. ${ }^{2}$

Turkish smokers are found to be more price sensitive than smokers in many countries. For example, the price elasticity of the poor group is estimated at $(-1.41)$ in Turkey, higher (in absolute value) than the price elasticity of the poor in the USA, where Hersch ${ }^{29}$ and Gruber and Köszegi ${ }^{20}$ report the price elasticity of the poor to be -1.18 , and -1.09 , respectively.

\section{Tax incidence simulation analysis}

The predicted and hypothetical excises paid and their share in total household expenditures by expenditure tertile are given in table 5. Although the burden of the current tax falls heavier on the low expenditure tertile (poor) where they spend $10.7 \%$ of their household expenditure on tobacco, the excise increases are estimated to be progressive. In fact, as excise taxes increase, the excise tax burden as a proportion of income decreases for the poor but the proportion of cigarette expenditures on total household expenditures declines for all tertiles.

The decline in the burden of tax increases is also supported by the progressivity coefficient and concentration curves. The coefficient was declining as the tax rate on cigarettes was increasing (table 6). Figure 1 shows that as excise tax on cigarettes increases by $50 \%$ and $75 \%$ from its current level, the cumulative distribution of the tax payments by expenditure tertiles approaches to the concentration curve of household expenditures (Lorenz curve). Although the burden of the taxes still persists, the proximity to Lorenz curve suggests that the burden on the poor declines (more progressive) with tax increases.

As excise tax increases, government tax revenue from cigarettes (excise+VAT) also increases at a moderate level (table 7). The contribution of the poor to total cigarette excise revenue declines as excise tax increases. In the pretax increase period (base case), the poor are estimated to contribute $23.8 \%$ of total cigarette excise revenue, and as the excise per pack increases by $75 \%$, the burden on the poor declines (more progressive) with tax increases. The rich, on the other hand, increase their contribution to almost half of the total excise tax revenue $(48.5 \%)$ as the excise per pack increases by $75 \%$, compared with their contribution of $42.2 \%$ at the pretax increase period. 
Table 3 Tobacco expenditure (Exp), excise revenue and its share in household (HH) expenditures per month

\begin{tabular}{|c|c|c|c|c|c|c|}
\hline $\begin{array}{l}\text { Expenditure } \\
\text { tertile }\end{array}$ & $\begin{array}{l}\text { Total consumption (in } \\
\text { thousand packs) }\end{array}$ & $\begin{array}{l}\text { Total HH exp by } \\
\text { smoking HHs (million } \\
\text { USD) }\end{array}$ & $\begin{array}{l}\text { Total cigarette exp } \\
\text { (million USD) }\end{array}$ & $\begin{array}{l}\text { Cigarettes exp. as a \% } \\
\text { of total HHs exp }\end{array}$ & $\begin{array}{l}\text { Total excise tax } \\
\exp \text { (million USD) }\end{array}$ & $\begin{array}{l}\text { Excise exp as a \% } \\
\text { of total HH exp }\end{array}$ \\
\hline The poor & 93963 & 792.4 & 79.1 & 10.0 & 41.1 & 5.2 \\
\hline The middle & 106916 & 1435.1 & 115.3 & 8.0 & 60.1 & 4.2 \\
\hline The rich & 112098 & 3178.0 & 143.8 & 4.5 & 74.8 & 2.4 \\
\hline $\begin{array}{l}\text { Total } \\
\text { households }\end{array}$ & 312977 & 5405.5 & 338.2 & 6.3 & 176.0 & 3.3 \\
\hline
\end{tabular}

Authors' calculations using the 2003 Turkish National Household Expenditure Survey data.

Table 4 Tobacco and total price (expenditure) elasticities by expenditure tertiles

\begin{tabular}{lccc}
\hline \multicolumn{4}{c}{ Expenditure tertiles } \\
\cline { 2 - 4 } & The poor & Middle & The rich \\
\hline Price (tobacco expenditure per pack) elasticity & & \\
Participation & -0.445 & -0.238 & -0.213 \\
& $(0.064)$ & $(0.067)$ & $(0.076)$ \\
Conditional demand & -0.967 & -0.577 & -0.528 \\
& $(0.140)$ & $(0.162)$ & $(0.187)$ \\
Total & -1.412 & -0.816 & -0.741 \\
& $(0.204)$ & $(0.229)$ & $(0.262)$ \\
Income (total household expenditure) elasticity & & \\
Participation & 0.073 & 0.023 & -0.009 \\
& $(0.023)$ & $(0.040)$ & $(0.017)$ \\
Conditional demand & 0.160 & 0.055 & -0.021 \\
& $(0.051)$ & $(0.098)$ & $(0.041)$ \\
Total & 0.233 & 0.078 & -0.030 \\
& $(0.075)$ & $(0.138)$ & $(0.058)$ \\
\end{tabular}

SE are reported in parentheses. The models specified in equations (1) and (2) are estimated 200 times. The values presented in this table are the estimated average elasticities using the coefficients on tobacco expenditures per pack (proxy for price) and total household expenditure (proxy for income) variables. All elasticity estimates are significant at $1 \%$.

\section{DISCUSSION AND CONCLUSION}

In recent years, many countries have tried to reform their tax system, mainly to increase the efficiency of tax collection, to facilitate its administration and to generate more revenues to be spent on social programmes. Although many countries enjoy higher revenues as they increase cigarette excise taxes, the policy decisions about such increases often pay little attention to their effect on inequality. In this study, we evaluate the progressivity of increases in excise tax in Turkey by using data from the 2003 THES. Our results show that when excise taxes increase, the burden of excises declines given the greater price sensitivity of smoking among lower income groups. This is more likely to be true in low-income/middle-income countries where there are similar patterns of tobacco use and where the same patterns for price sensitivity are likely. Furthermore, the tax-induced increase in total revenues could be used to compensate for the tax-induced burden on the poor, offsetting the burden even further.

Increasing tobacco excise taxes is good for both fiscal and health policy. ${ }^{30} 31$ Clearly, one way to offset the burden of tobacco taxes may be to generate revenues to be spent in a progressive manner, especially on social programmes that the poor would benefit from, instead of reducing excise tax rates or significantly differentiating tax rates among tobacco products to alleviate the burden of excise taxes on poor smokers. Indeed,

Table 5 Predicted and hypothetical tax paid as a per cent of household expenditure

\begin{tabular}{|c|c|c|c|c|}
\hline & \multicolumn{3}{|c|}{ Expenditure tertiles } & \multirow[b]{2}{*}{ Overall (\%) } \\
\hline & The poor (\%) & Middle (\%) & The rich (\%) & \\
\hline \multicolumn{5}{|c|}{ Predicted excise expenditures as a per cent of smoker household expenditures } \\
\hline Base case & 5.5 & 4.3 & 2.4 & 3.4 \\
\hline Hypothetical $10 \%$ excise increase & 5.5 & 4.5 & 2.5 & 3.5 \\
\hline Hypothetical $25 \%$ excise increase & 5.3 & 4.7 & 2.7 & 3.6 \\
\hline Hypothetical $50 \%$ excise increase & 4.6 & 4.8 & 2.8 & 3.6 \\
\hline Hypothetical $75 \%$ excise increase & 3.3 & 4.7 & 2.9 & 3.4 \\
\hline \multicolumn{5}{|c|}{ Predicted cigarette expenditures as a per cent of smoker household expenditures } \\
\hline Base case & 10.7 & 8.3 & 4.7 & 6.5 \\
\hline Hypothetical $10 \%$ excise increase & 10.3 & 8.4 & 4.7 & 6.5 \\
\hline Hypothetical $25 \%$ excise increase & 9.6 & 8.4 & 4.8 & 6.4 \\
\hline Hypothetical $50 \%$ excise increase & 7.9 & 8.1 & 4.7 & 6.1 \\
\hline Hypothetical $75 \%$ excise increase & 5.4 & 7.6 & 4.5 & 5.4 \\
\hline \multicolumn{5}{|c|}{$\begin{array}{l}\text { In estimating the excise expenditures in the base case, we predict the prevalence rate and consumption for each household by using the estimated coefficients of equations (1) and ( } 2 \text { ) } \\
\text { and calculate their mean predicted prevalence rate, } \overline{\pi_{k}} \text {, and mean predicted consumption level equivalent to a pack of } 20 \text { cigarettes for each expenditure tertile } k \text {, } E_{k} \text {. Then they are } \\
\text { multiplied with the excise tax per pack and the weighted number of the household in each tertile to calculate the total excise tax expenditure in each tertile. The new cigarette } \\
\text { expenditures after the excise tax increase are predicted in a similar way using the percentage change in price with excise tax increase and price elasticities reported in table } 4 . \\
\text { Before the number of cigarettes smoked by each household is estimated, the existence of heteroscedasticity is estimated for each tertile using the White test. We did not reject the null } \\
\text { hypothesis that the variance of the residuals is homogeneous for each expenditure tertile. Moreover, we did not reject the normality of the residuals. In order to not impose the } \\
\text { normality distribution of the error terms, we assume that the distribution of the error term is not known and a non-parametric smearing estimator is used. }{ }^{34} \text { Hence, the smearing } \\
\text { estimator is calculated as follows }{ }^{35}: \phi=(1 / N)\left(\sum_{\mathrm{i}=1}^{\mathrm{N}} \mathrm{e}^{\tilde{\mathrm{A}}}\right)\end{array}$} \\
\hline
\end{tabular}


Table 6 Progressivity coefficient at the current excise tax rate and when excise taxes are increased by $50 \%$ and $75 \%$

\begin{tabular}{lclc}
\hline & \multirow{2}{*}{$\begin{array}{l}\text { Current excise } \\
\text { Tax level }\end{array}$} & \multicolumn{2}{c}{ Increase in excise tax } \\
\cline { 3 - 4 } & $\mathbf{5 0 \%}$ & $\mathbf{7 5 \%}$ \\
\hline Progressivity coefficient & -0.2028 & -0.1306 & -0.0676 \\
\hline
\end{tabular}

since tobacco has the potential to generate more revenue for governments, at least in the short term, redistribution policies might favour the poor by encouraging governments to spend more funds on education, health and social assistance programmes. These programmes would be beneficial not only for poor smokers but also for the poor in general. In fact, this is exactly what the Turkish government has done, by implementing effective tobacco control policies and allocating more money on smoking cessation programmes. As a result, between 2008 and 2012, Turkey reduced its overall prevalence rate of smoking from $32 \%$ to $27 \% .^{24}$

The existing literature suggests that the long-term price elasticities are higher than the short-term price estimates. ${ }^{2}$ Although we did not estimate the long-run price elasticities in this study, we expect that in the long run, households in the low-income group will continue to reduce their expenditure more than those in the higher income groups. Furthermore, the Turkish government generates significant revenues from cigarettes, and can allocate funds for programmes that benefit the poor. In fact, the Turkish government introduced national health insurance, significantly subsidised for the poor.

In the interpretation of the results, one should keep in mind that the results are based on the elasticity estimates using expenditures and at the household level rather than individual level. The use of household elasticity may result in the underestimation of price elasticity because none of the household members will purchase any cigarettes for that household which is considered as a non-smoker household. On the contrary, Deaton ${ }^{32}$ points out that the use of prices calculated as a ratio of household cigarette expenditures to total cigarette purchases may
Table 7 Contribution of expenditure tertiles to government revenues

\begin{tabular}{|c|c|c|c|c|}
\hline & \multicolumn{3}{|c|}{ Expenditure tertiles } & \multirow[b]{2}{*}{ Overall } \\
\hline & The poor & Middle & The rich & \\
\hline \multicolumn{5}{|c|}{ Government revenues (in billion TL) when excise tax increases by } \\
\hline Base case & 61044 & 86861 & 108114 & 256019 \\
\hline $10 \%$ & 61312 & 90735 & 113495 & 265542 \\
\hline $25 \%$ & 59734 & 94912 & 119723 & 274369 \\
\hline $50 \%$ & 51827 & 97521 & 125186 & 274535 \\
\hline $75 \%$ & 37328 & 94690 & 124507 & 256526 \\
\hline \multicolumn{5}{|c|}{ Government revenues (in thousand \$US) when excise tax increases by } \\
\hline Base case & 43244 & 61533 & 76589 & 181367 \\
\hline $10 \%$ & 43434 & 64278 & 80401 & 188113 \\
\hline $25 \%$ & 42316 & 67237 & 84813 & 194366 \\
\hline $50 \%$ & 36715 & 69085 & 88683 & 194484 \\
\hline $75 \%$ & 26444 & 67079 & 88202 & 181726 \\
\hline \multicolumn{5}{|c|}{ Share of expenditure tertiles to government revenue when excise tax increases by } \\
\hline Base case & $23.8 \%$ & $33.9 \%$ & $42.2 \%$ & \\
\hline $10 \%$ & $23.1 \%$ & $34.2 \%$ & $42.7 \%$ & \\
\hline $25 \%$ & $21.8 \%$ & $34.6 \%$ & $43.6 \%$ & \\
\hline $50 \%$ & $18.9 \%$ & $35.5 \%$ & $45.6 \%$ & \\
\hline $75 \%$ & $14.6 \%$ & $36.9 \%$ & $48.5 \%$ & \\
\hline
\end{tabular}

Base case refers to the case before the increase in excise tax. Government revenues are estimated as a sum of excise taxes and value-added taxes paid by households in each tertile $k$, using the following equation:

Government revenue $=\sum_{\mathrm{k}=1}^{3} C_{\mathrm{k}} \times\left[1+\left(\varepsilon_{\mathrm{k}} \delta_{\mathrm{k}}\right)\right] \times \overline{\overline{T_{\mathrm{k}}}}+\sum_{\mathrm{k}=1}^{3} \mathrm{C}_{\mathrm{k}} \times\left[1+\left(\varepsilon_{\mathrm{k}} \delta_{\mathrm{k}}\right)\right] \times \overline{\overline{V_{\mathrm{k}}}}$ where $C_{k}$ is the total consumption of smoker households in tertile $k$ in the base case, $\varepsilon_{k}$ is the total price elasticity of cigarettes of tertile $k$ and $\delta_{k}$ is the percentage change in the average price of cigarettes purchased by the households in tertile $k$ because of the increase in excise tax for the increase in excise taxes by $10 \%, 25 \%$, $50 \%$ or $75 \%$.

result in the overestimation of price elasticities if households switch to lower priced cigarettes when their prices increase. Classification of households into tertiles based on their total expenditures rather than their income can be considered as a strength of this study because Poterba ${ }^{33}$ argues that an
Figure 1 Concentration curve for total excise tax payments on cigarettes and the Lorenz curve for household expenditures.

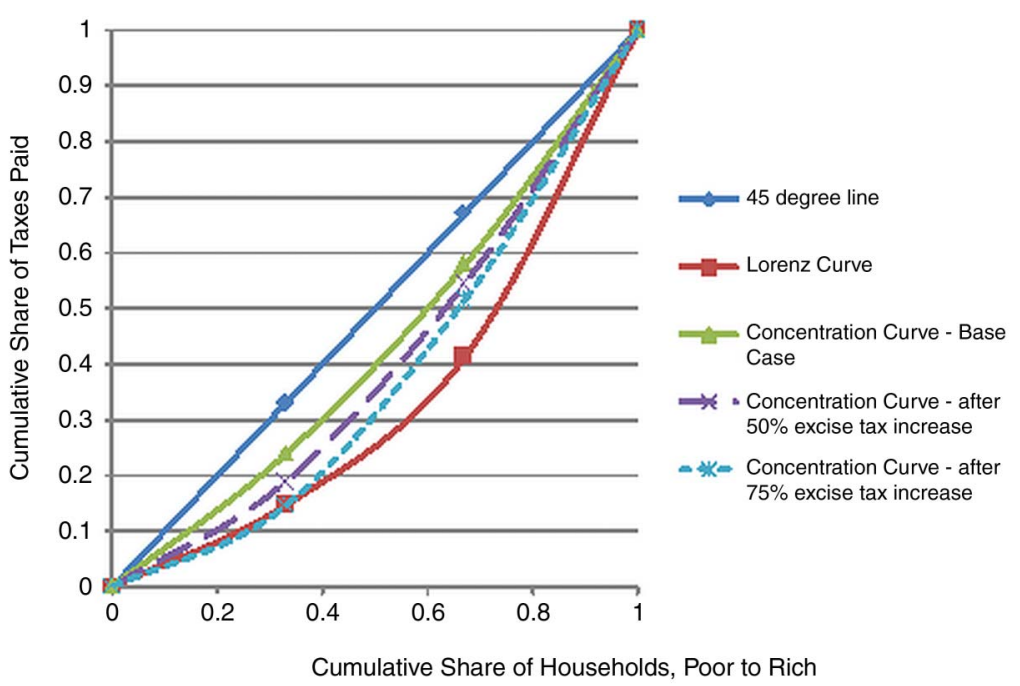

Note: The concentration curves of excise tax payments before and after tax change are estimated with the shares of each tertile's excise payments. The vertical axis shows the cumulative shares of each tertile on tax payments. Similarly, Lorenz curve shows the cumulative share of total household expenditures by expenditure tertiles. The 45-degree line represents the case where the share of total household expenditures is assumed to be equal to 0.33 across all tertiles. 
individual's income varies over time and these changes might affect the estimated distributional burden of excise taxes.

\section{What this paper adds}

- The literature shows that the current excise taxes on tobacco are regressive based on the traditional regressivity argument, that is, the poor pay a higher share of their income for tobacco excise taxes than the rich, but increases in taxes are assumed to be not regressive due to the higher sensitivity of the poor who are expected to quit or reduce their consumption dramatically.

- It is known that governments generate more revenue as tax increases but none of the research clearly shows who is the largest taxpayer from the equity perspective.

- This study looks at the regressivity argument (inequality of tax payments) by applying a different technique, that is, by using the Lorenz curve for tobacco taxes, and shows that increases in excise tax are indeed progressive.

- It also shows that the traditional regressivity argument falls short for higher tax policies: higher taxes are progressive, paid practically by the rich and high-income groups, and the part of increased revenues can be allocated for social programmes from which not only the poor smokers but also the poor can benefit the most.

Contributors $Z O ̈$ and AAY have contributed to the design, analysis and interpretation of data, drafting of the article and revising it critically for important intellectual content, and final approval of the version to be published. Both assure that there is no one else who fulfills the criteria but has not been included as an author.

Competing interests None.

Provenance and peer review Not commissioned; externally peer reviewed.

\section{REFERENCES}

1 Gajalakshmi, CK, Jha P, Ranson K, et al. Global patterns of smoking and smokingattributable mortality. In: Jha P, Chaloupka F, eds. Tobacco control in developing countries. New York: Oxford University Press, 2000, 11-39.

2 International Agency for Research on Cancer. IARC handbooks of cancer prevention, tobacco control, vol. 14: effectiveness of tax and price policies for tobacco control. Lyon, France: IARC, 2011

3 Browning EK. The burden of taxation. J Polit Econ 1978:86:649-71.

4 Townsend JL. Cigarette tax, economic welfare and social class patterns of smoking. App/ Econ 1987; 19:355-65.

5 Townsend JL, Roderick P, Cooper J. Cigarette smoking by socioeconomic group, sex and age: effects of price, income and health publicity. Brit Med J 1994;309:923-7.

6 Congress of the United States, Congressional Budget Office. Federal taxation of tobacco, alcoholic beverages and motor fuels. Washington, DC: US Government Printing Office, 1990.

7 Congress of the United States, Congressional Budget Office. Historic effective tax rates, 1979-1997. Washington DC: US Government Printing Office, 2001
8 Borren $\mathrm{P}$, Sutton M. Are increases in cigarette taxation regressive? Health Econ 1992:1:245-53.

9 Fullerton D, Rogers DL. Who bears the lifetime tax burden? Washington, DC: Brookings Institution, 1993.

10 Lyon $A B$, Schwab RM. Consumption taxes in a life-cycle framework: are sin taxes regressive? Rev Econ Statistics 1995;77:389-406.

11 Evans W, Ringel J, Stech D. Tobacco taxes and public policy to discourage smoking In: Poterba J, ed. Tax policy and the economy. 1999;13:1-56.

12 Viscusi WK. The new cigarette paternalism: there are better ways to address smoking than ever-increasing cigarette taxes. Regulation 2002-2003;25:58-64.

13 Colman G, Remler DK. Vertical equity consequences of very high cigarette tax increases: ff the poor are the ones smoking, how could cigarette tax increases be progressive? J Policy Anal Manage 2008;27:376-400.

14 Önder Z. Economics of Tobacco Control in Turkey. HNP Discussion Paper, Economics of Tobacco Control Paper, no. 2. Washington, DC: The International Bank for Reconstruction and Development/The World Bank, 2002.

15 Karki YB, Kiran DP, Pande BR. Study on the Economics of Tobacco in Nepal. HNP Discussion Paper, Economics of Tobacco Control Paper, no.13. Washington, DC: The International Bank for Reconstruction and Development/The World Bank, 2003.

16 Arunatilake N, Opatha M. The Economics of Tobacco in Sri Lanka. HNP Discussion Paper, Economics of Tobacco Control Paper, no.12. Washington, D.C: The International Bank for Reconstruction and Development/The World Bank, 2003.

17 Adioetomo SM, Djutaharta T, Hendratno. Cigarette consumption, taxation, and household income: Indonesia case study. HNP Discussion Paper-Economics of Tobacco Control Paper, no.26. Washington, DC: The World Bank, 2005

18 Remler DK. Poor smokers, poor quitters and cigarette tax regressivity. Am J Public Health 2004;94:225-9.

19 Chaloupka FJ, Warner KE. The economics of smoking. In: Culyer AJ, Newhouse JP, eds. Handbook of health economics, Vol 1. Amsterdam: Elsevier, 2000:1539-627.

20 Gruber J, Köszegi B. Tax incidence when individuals are time-inconsistent: the case of cigarette excise taxes. J Public Econ 2004;88:1959-87.

21 Gospodinov N, Irvine I. Tobacco taxes and regressivity. J Health Econ 2009;28:375-84

22 Younger SD, Sahn DE, Haggblade S, et al. Tax incidence in Madagascar: an analysis using household data. The World Bank Econ Rev 1999;13:303-31.

23 Rajemison $\mathrm{H}$, Haggblade S, Younger SD. Indirect tax incidence in Madagascar: updated estimates using the input-output table. Working paper \#147. Cornell University, Food and Nutrition Policy Program, 2003.

24 GATS. Global adult tobacco survey, fact sheet, Turkey. 2012. http://global. tobaccofreekids.org/files/pdfs/en/GATS_factsheet_turkey_2012.pdf

25 Yitzhaki S, Slemrod J. Welfare dominance: an application to commodity taxation. Am Econ Rev 1991;81:480-96.

26 Younger SD. Estimating tax incidence in Ghana: an exercise using household data Cornell Food and Nutrition Policy Program Working Paper 48. CFNPP Publications Department, Ithaca, NY, 1993.

27 Cragg JG. Some statistical models for limited dependent variables with application to the demand for durable goods. Econometrica 1971;39:829-44.

28 Deaton A. The analysis of household surveys: a microeconomic approach to development policy. Baltimore, Maryland: John Hopkins University Press, 1997.

29 Hersch J. Gender, income levels, and the demand for cigarettes. J Risk Uncertain 2000;21:263-82

30 WHO. Techical manual on tobacco tax administration. Genera, Switzerlad: WHO Press, 2011.

31 Owen D, Bassett S, Lane C, et al. Georgia: recent economic developments and selected issues. IMF Country Reports, No. 211, 2001.

32 Deaton A. Quality, quantity and spatial variation of price. Am Econ Rev 1988:78:418-30

33 Poterba JM. Lifetime incidence and the distributional burden of excise taxes. Am Econ Rev 1989;79:325-30.

34 Duan N. Smearing estimate: a nonparametric retransformation method. J Am Stat Assoc 1983;78:605-10.

35 Tauras JA. An empirical analysis of adult cigarette demand. East Econ J 2005:31:361-75 
$\mathrm{TC}$

\section{Who pays the most cigarette tax in Turkey}

Zeynep Önder and Ayda A Yürekli

Tob Control 2016 25: 39-45 originally published online September 16, 2014

doi: 10.1136/tobaccocontrol-2014-051639

Updated information and services can be found at:

http://tobaccocontrol.bmj.com/content/25/1/39

These include:

Supplementary Supplementary material can be found at:

Material http://tobaccocontrol.bmj.com/content/suppl/2014/09/16/tobaccocon trol-2014-051639.DC1

References This article cites 19 articles, 1 of which you can access for free at: http://tobaccocontrol.bmj.com/content/25/1/39\#BIBL

Email alerting service

Receive free email alerts when new articles cite this article. Sign up in the box at the top right corner of the online article.

\section{Notes}

To request permissions go to:

http://group.bmj.com/group/rights-licensing/permissions

To order reprints go to:

http://journals.bmj.com/cgi/reprintform

To subscribe to BMJ go to:

http://group.bmj.com/subscribe/ 